\title{
Diazepam and Meperidine on Arterial Blood Gases in Healthy Volunteers
}

ELEMÉR K. ZSIGMOND, M.D., KATHY FLYNN, B.S., and Orestes A. MARTINez, M.D. Ann Arbor, Mich.

\begin{abstract}
A RTERIal blood gases and $\mathrm{pH}$ may re$A_{\text {flect }}$ the respiratory depression produced by tranquilizing and narcoticanalgesic agents used in premedication before surgical anesthesia. The absence of respiratory depression is one of the desirable qualities of an ideal premedicant or sedative drug. Therefore, it is essential to know if, and to what extent, a particular drug depresses respiration. The respiratory depressant effect of drugs is especially important in patients with pulmonary disease, in whom care must be exercised in selecting an agent that will not be detrimental to ventilation.

Respiratory depression has been reported to occur following the use of phenothiazine tranquilizers and barbiturates. ${ }^{1,2}$ Therefore, we wanted to verify the claim $^{3,4}$ that diazepam does not induce significant respiratory depression or potentiate the depression caused by meperidine in healthy volunteers.
\end{abstract}

\section{Materials and Methods}

Thirty-six healthy volunteers were adult students and hospital employees between the ages of 19 and 62 years $($ mean $=35)$. An almost equal number of males and females were present in each

From the Department of Anesthesiology, University of Michigan Medical Center, Ann Arbor, Michigan 48104.

July, 1974 study group, as shown in Table I. The volunteers were recumbent during the tests.

After insertion of a 20-gauge Riley arterial needle into the left brachial artery and the start of an intravenous infusion of $5 \%$ glucose in $0.2 \%$ sodium chloride in the contralateral arm, a period of rest was allowed. Two arterial samples were then drawn at 10-minute intervals as baseline samples. If the two determinations differed less than $5 \%$, the study was begun.

Meperidine $1.5 \mathrm{mg} / \mathrm{kg}$, diazepam 0.15 $\mathrm{mg} / \mathrm{kg}$, or meperidine $1.5 \mathrm{mg} / \mathrm{kg}$ and diazepam $0.15 \mathrm{mg} / \mathrm{kg}$ in combination in alternate sequence were infused intravenously over a 2-minute period. Timing was begun at the end of this period.

The oxygen tension was directly determined with a Clark-Oxygen-Electrode and the carbon dioxide tension by a $\mathrm{pCO}_{2}$ electrode of IL-113 $\mathrm{pH}-\mathrm{Blood}$ Gas Analyzer (Instrumentation Laboratories, Inc.) or with Siggard-Andersen's technique on a Radiometer Copenhagen $\mathrm{pH}-$ Blood Gas Analyzer, before and at 5minute intervals after administration of the test medication for 1 hour. The $\mathrm{pH}$ was directly measured with the glass electrode of the IL-113 pH-blood gas analyzer or the Radiometer glass electrode at the same time intervals. 
ZSIGMOND, FLYNN, AND MARTINEZ

TABLE I

Age and Sex Distribution of 36 Healthy Volunteers

\begin{tabular}{|c|c|c|c|c|}
\hline \multirow[b]{2}{*}{ Drug study groups } & \multirow[b]{2}{*}{$\mathbf{N}$} & \multicolumn{2}{|c|}{ Sexes } & \multirow{2}{*}{ 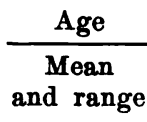 } \\
\hline & & Male & Female & \\
\hline $\begin{array}{l}\text { Diazepam } \\
0.15 \mathrm{mg} / \mathrm{kg}\end{array}$ & 10 & 5 & 5 & $\begin{array}{c}39.7 \\
(20-57)\end{array}$ \\
\hline $\begin{array}{l}\text { Meperidine } \\
1.5 \mathrm{mg} / \mathrm{kg}\end{array}$ & 19 & 11 & 8 & $\begin{array}{c}32.4 \\
(19-62)\end{array}$ \\
\hline $\begin{array}{l}\text { Diazepam } \\
0.15 \mathrm{mg} / \mathrm{kg} \\
\text { and } \\
\text { meperidine } \\
1.5 \mathrm{mg} / \mathrm{kg}\end{array}$ & 7 & 4 & 3 & $\begin{array}{c}38.9 \\
(21-53)\end{array}$ \\
\hline
\end{tabular}

\section{Results}

In the healthy volunteers, the maximum reduction in $\mathrm{PaO}_{2}$ after meperidine was 11.5 Torr, after the meperidine and diazepam combination, 5.3 Torr, and after diazepam, 5.3 Torr, as shown in Table II and Fig. 1. The change after diazepam alone was not statistically significant $(P>0.05)$. There was, however, a significant decrease in $\mathrm{PaO}_{2}$ after the intravenous injection of meperidine $(P<0.01)$. The combination of diazepam with meperidine caused no more decrease in $\mathrm{PaO}_{2}$ than meperidine alone $(P>0.05)$. As Fig. 1 shows, the reduction in $\mathrm{PaO}_{2}$ lasted for only 20 minutes following meperidine and meperidine-diazepam combination, and diazepam caused no prolongation of the period of reduced $\mathrm{PaO}_{2}$ induced by meperidine.

TABIEF II

$\mathrm{PaO}_{2}$ in Healthy Volunteers Given Diazepam and Meperidine Alone and in Combination

\begin{tabular}{|c|c|c|c|c|c|c|}
\hline \multirow{2}{*}{$\begin{array}{l}\text { Intravenous } \\
\text { medications } \\
\text { and dose }\end{array}$} & \multirow{2}{*}{$\begin{array}{c}\text { Control } \\
\text { value } \\
\text { (means } \pm \\
\text { S.D.) }\end{array}$} & \multicolumn{5}{|c|}{ Torr values after medication (means \pm S.D.) } \\
\hline & & $5 \mathrm{~min}$ & $10 \min$ & $20 \min$ & $30 \mathrm{~min}$ & $60 \mathrm{~min}$ \\
\hline $\begin{array}{l}\text { Diazepam } \\
0.15 \mathrm{mg} / \mathrm{kg}\end{array}$ & $\begin{array}{c}86.5 \\
\pm 6.06\end{array}$ & $\begin{array}{c}81.2 \\
\pm 10.54\end{array}$ & $\begin{array}{c}85.3 \\
\pm 8.59\end{array}$ & $\begin{array}{c}84.8 \\
\pm 6.76\end{array}$ & $\begin{array}{c}84.8 \\
\pm 8.06\end{array}$ & $\begin{array}{l}87.8 \\
\pm 6.34\end{array}$ \\
\hline $\begin{array}{l}\text { Meperidine } \\
1.5 \mathrm{mg} / \mathrm{kg}\end{array}$ & $\begin{array}{c}85.3 \\
\pm 9.48\end{array}$ & $\begin{array}{c}73.8 \\
\pm 9.52\end{array}$ & $\begin{array}{r}80.6 \\
\pm 11.12\end{array}$ & $\begin{array}{c}83.9 \\
\pm 8.85\end{array}$ & $\begin{array}{c}82.3 \\
\pm 9.26\end{array}$ & $\begin{array}{r}83.8 \\
\pm 10.86\end{array}$ \\
\hline $\begin{array}{l}\text { Diazepam } \\
0.15 \mathrm{mg} / \mathrm{kg} \\
\text { and } \\
\text { meperidine } \\
1.5 \mathrm{mg} / \mathrm{kg}\end{array}$ & $\begin{array}{c}80.7 \\
\pm 3.55\end{array}$ & $\begin{array}{c}\mathbf{7 5 . 4} \\
\pm 17.73\end{array}$ & $\begin{array}{c}\mathbf{7 9 . 3} \\
\pm 12.75\end{array}$ & $\begin{array}{c}80.1 \\
\pm 8.63\end{array}$ & $\begin{array}{c}81.3 \\
\pm 8.85\end{array}$ & $\begin{array}{c}85.0 \\
\pm 5.83\end{array}$ \\
\hline
\end{tabular}




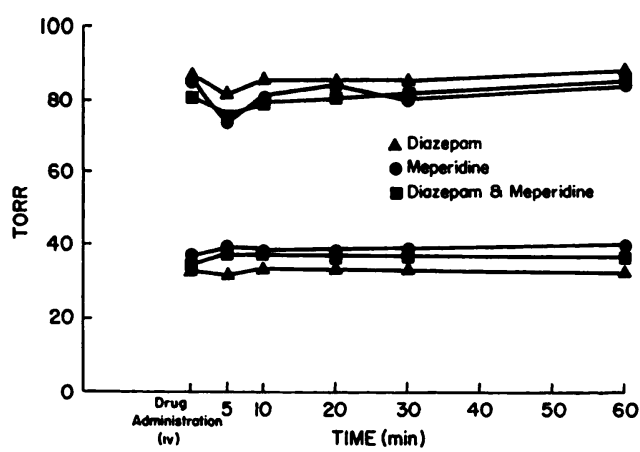

Fig. 1. Changes in $\mathrm{PaO}_{2}$ and $\mathrm{PaCO}_{2}$ in healthy volunteers given intravenously diazepam, meperidine, and their combinations. The upper lines represent $\mathrm{PaO}_{2}$, the lower lines $\mathrm{PaCO}_{2}$.

No increase in arterial $\mathrm{PaCO}_{2}$ occurred after diazepam alone, which corroborates the lack of respiratory depressant effect. The maximum increase in $\mathrm{PaCO}_{2}$ in the healthy volunteers was 1.4 Torr after meperidine and 3.1 Torr after the meperidine and diazepam combination, as shown in Table III and Fig. 1. It is of great importance that the increase in $\mathrm{PaCO}_{2}$ was not significantly greater following the diazepam-meperidine combina- tion than following meperidine alone, $(P>0.05)$, and the differences in resting $\mathrm{PaCO}_{2}$ values might have partly explained this difference.

Changes in $\mathrm{pH}$ of the arterial blood were not statistically significant in any of the groups, as seen in Table IV.

\section{Discussion}

Our results corroborate the findings of Sadove et $a .^{4}$ and Steen et $a .^{3}$ who observed no changes in the respiratory response to carbon dioxide following 0.15 $\mathrm{mg} / \mathrm{kg}$ diazepam intramuscularly and $0.66 \mathrm{mg} / \mathrm{kg}$ intravenously. Furthermore, the combination of diazepam with meperidine caused no greater shift in the $\mathrm{CO}_{2}$ response curve than meperidine alone in their studies. Huettemann et al. ${ }^{5}$ also confirmed the complete lack of respiratory depression by spirometric studies in ten healthy persons who received $10 \mathrm{mg}$ diazepam intravenously. They also observed no alteration in the response of the respiratory center to carbon dioxide. This lack of respiratory depressant effect of diazepam is further confirmed by our blood gas studies with

TABLE III

$\mathrm{PaCO}_{2}$ in Healthy Volnnteers Given Diazepam and Meperidine Alone and in Combination

\begin{tabular}{|c|c|c|c|c|c|c|}
\hline \multirow{2}{*}{$\begin{array}{l}\text { Intravenous } \\
\text { medications } \\
\text { and dose }\end{array}$} & \multirow{2}{*}{$\begin{array}{c}\text { Control } \\
\text { value } \\
\text { (means } \pm \\
\text { S.D.) }\end{array}$} & \multicolumn{5}{|c|}{ Torr values after medication (means \pm S.D.) } \\
\hline & & $5 \min$ & $10 \mathrm{~min}$ & $20 \mathrm{~min}$ & $30 \mathrm{~min}$ & $60 \min$ \\
\hline $\begin{array}{l}\text { Diazepam } \\
0.15 \mathrm{mg} / \mathrm{kg}\end{array}$ & $\begin{array}{c}32.8 \\
\pm 4.73\end{array}$ & $\begin{array}{c}31.8 \\
\pm 3.67\end{array}$ & $\begin{array}{c}33.0 \\
\pm 2.82\end{array}$ & $\begin{array}{c}33.2 \\
\pm 3.14\end{array}$ & $\begin{array}{c}33.1 \\
\pm 2.80\end{array}$ & $\begin{array}{c}32.1 \\
\pm 3.52\end{array}$ \\
\hline $\begin{array}{l}\text { Meperidine } \\
1.5 \mathrm{mg} / \mathrm{kg}\end{array}$ & $\begin{array}{c}37.6 \\
\pm 3.80\end{array}$ & $\begin{array}{c}39.0 \\
\pm 3.22\end{array}$ & $\begin{array}{c}38.0 \\
\pm 4.04\end{array}$ & $\begin{array}{c}38.5 \\
\pm 3.28\end{array}$ & $\begin{array}{c}38.9 \\
\pm 3.75\end{array}$ & $\begin{array}{c}39.2 \\
\pm 3.38\end{array}$ \\
\hline $\begin{array}{l}\text { Diazepam } \\
0.15 \mathrm{mg} / \mathrm{kg} \\
\text { and } \\
\text { meperidine } \\
1.5 \mathrm{mg} / \mathrm{kg}\end{array}$ & $\begin{array}{c}34.1 \\
\pm 2.65\end{array}$ & $\begin{array}{c}37.2 \\
\pm 3.50\end{array}$ & $\begin{array}{c}37.1 \\
\pm 5.08\end{array}$ & $\begin{array}{c}36.5 \\
\pm 3.76\end{array}$ & $\begin{array}{c}36.9 \\
\pm 4.59\end{array}$ & $\begin{array}{c}36.8 \\
\pm 4.44\end{array}$ \\
\hline
\end{tabular}

July, 1974 
ZSIGMOND, FLYNN, AND MARTINEZ

TABLE IV

pH in Healthy Volunteers Given Diazepam and Meperidine Alone and in Combination

\begin{tabular}{|c|c|c|c|c|c|c|}
\hline \multirow{2}{*}{$\begin{array}{l}\text { Intravenous } \\
\text { medications } \\
\text { and dose }\end{array}$} & \multirow{2}{*}{$\begin{array}{c}\text { Control } \\
\text { value } \\
\text { (mean } \pm \\
\text { S.D.) }\end{array}$} & \multicolumn{5}{|c|}{ Torr values after medication (means \pm S.D.) } \\
\hline & & $5 \min$ & $10 \mathrm{~min}$ & $20 \mathrm{~min}$ & $30 \mathrm{~min}$ & $60 \min$ \\
\hline $\begin{array}{l}\text { Diazepam } \\
0.15 \mathrm{mg} / \mathrm{kg}\end{array}$ & $\begin{array}{r}7.415 \\
\pm 0.038\end{array}$ & $\begin{array}{r}7.378 \\
\pm \mathbf{0 . 0 3 0}\end{array}$ & $\begin{array}{r}7.386 \\
\pm 0.031\end{array}$ & $\begin{array}{r}7.423 \\
+0.036\end{array}$ & $\begin{array}{r}7.437 \\
\pm \mathbf{0 . 0 3 0}\end{array}$ & $\begin{array}{r}7.432 \\
\pm 0.033\end{array}$ \\
\hline $\begin{array}{l}\text { Meperidine } \\
1.5 \mathrm{mg} / \mathrm{kg}\end{array}$ & $\begin{array}{r}7.399 \\
\pm 0.020\end{array}$ & $\begin{array}{r}7.382 \\
\pm 0.031\end{array}$ & $\begin{array}{r}7.382 \\
\pm 0.027\end{array}$ & $\begin{array}{r}7.379 \\
\pm 0.023\end{array}$ & $\begin{array}{r}7.381 \\
\pm 0.020\end{array}$ & $\begin{array}{r}7.382 \\
\pm 0.027\end{array}$ \\
\hline $\begin{array}{l}\text { Diazepam } \\
0.15 \mathrm{mg} / \mathrm{kg} \\
\text { and } \\
\text { meperidine } \\
1.5 \mathrm{mg} / \mathrm{kg}\end{array}$ & $\begin{array}{r}7.406 \\
\pm 0.032\end{array}$ & $\begin{array}{r}7.386 \\
\pm 0.044\end{array}$ & $\begin{array}{r}7.384 \\
\pm 0.046\end{array}$ & $\begin{array}{r}7.391 \\
\pm \mathbf{0 . 0 3 9}\end{array}$ & $\begin{array}{r}7.389 \\
\pm 0.040\end{array}$ & $\begin{array}{r}7.395 \\
\pm 0.032\end{array}$ \\
\hline
\end{tabular}

the combined administration of diazepam with a known respiratory depressant dose of meperidine. As noted in Fig. 1, diazepam had no additive effect with meperidine and caused no potentiation of the respiratory depression caused by meperidine, which agrees with the findings of Steen et al. ${ }^{8}$

Although the above findings confirm the lack of respiratory depression with 10 mg diazepam in healthy individuals, cardiac patients may develop respiratory depression following this dose of diazepam according to the report of Dalen et al. ${ }^{6}$ They found hypoventilation in all patients scheduled for cardiac catheterization following $5-10 \mathrm{mg} / 70 \mathrm{~kg}$ diazepam intravenously. That respiratory depression may follow the administration of a larger dose, $20 \mathrm{mg}$ diazepam intramuscularly, was reported by Herberg et al. ${ }^{7}$ These authors observed a decrease in the respiratory response to carbon dioxide in 74 young test persons. Moreover, Buskop et al. ${ }^{8}$ reported respiratory arrest in a patient during epidural anesthesia who received $10 \mathrm{mg}$ diazepam intravenously. In this case, hypersensitivity to diazepam is a more likely cause than is respiratory depression. Our preliminary results, from a pilot study in patients with chronic obstructive lung disease and mitral stenosis with arterial fibrillation, contradict these findings, since $10 \mathrm{mg} / 70 \mathrm{~kg}$ diazepam intravenously caused no alteration in arterial blood gases. ${ }^{\theta}$ Furthermore, clinical experience with several thousand patients who underwent cardioversion ${ }^{10}$ or surgery under regional anesthesia supplemented with $0.2 \mathrm{mg} / \mathrm{kg}$ intravenous diazepam or sedated with $10 \mathrm{mg} / 70 \mathrm{~kg}$ diazepam further attests to the lack of respiratory depression with this agent in the doses recommended.

\section{Summary}

Arterial blood gases were not significantly altered by $0.15 \mathrm{mg} / \mathrm{kg}$ I.V. dose of diazepam in healthy volunteers. The $\mathrm{PaO}_{2}$ was significantly reduced and the $\mathrm{PaCO}_{2}$ increased following the administration of meperidine $1.5 \mathrm{mg} / \mathrm{kg}$ intravenously and the combination of meperidine $1.5 \mathrm{mg} / \mathrm{kg}$ with diazepam 0.15 $\mathrm{mg} / \mathrm{kg}$. Diazepam did not significantly increase the respiratory depression induced

The Journal of Clinical Pharmacology 


\section{DIAZEPAM AND MEPERIDINE ON BLOOD GASES}

by meperidine. Values for arterial $\mathrm{pH}$ were not significantly affected in any of the groups.

\section{Acknowledgments}

We are grateful to Hoffmann-La Roche Inc. for their generous support of our investigations and for the statistical analysis of the data.

\section{References}

1. Eckenhoff, J. E., Helrich, M., Hege, J. J. D. and Jones, R. E.: Respiratory hazards of opiates and other narcotic analgesics. Surg. Gynec. Obstet. 101:701 (1955).

2. Pierce, J. A., and Garofalvo, M. L.: Preoperative medication and its effect on blood gases. J.A.M.A. $194: 487$ (1965).

3. Steen, S. N., Weitzner, S. W., Amaha, K., and Martinez, L. R.: The effect of diazepam on the respiratory response to carbon dioxide. Canad. Anaesth. Soc. J. 13:374 (1966).

4. Sadove, M. S., Balagot, R. C., and McGrath, J. M.: Effects of chlordiazepoxide and diazepam on the influence of meperidine on the respiratory response to carbon dioxide. J. New Drugs 5:121 (1965).

5. Huettemann, U., Kunkel, G., and Kaefer- stein, R.: The influence of diazepam and chlordiazepoxide on the respiration of healthy and emphysematous men. Pharmacol. Clin. 1:139 (1969).

6. Dalen, J. E., Evans, G. L., Banas, J. S., Jr. Brooks, H. L., Paraskos, J. A., and Dexter, L: The hemodynamic and respiratory effects of diazepam (Valium(B). Anesthesiol. 30:259 (1969).

7. Herberg, D., Geisler, L., Bohr, W., and Utz, G.: Investigations on the effect of different drugs on the $\mathrm{CO}_{2}$-sensitive central regulation of respiration in man, by means of $\mathrm{CO}_{2}$-response-curves. Pharmacol. Clin. 1:54 (1968).

8. Buskop, J. J., Price, M., and Molnar, I.: Untoward effect of diazepam. New Eng. J. Med. $277: 316$ (1967).

9. Zsigmond, E. K., and Shively, J. G.: Blood gas studies on the respiratory depressant effect of tranquilizers, narcotic-analgesics and their combination in human volunteers. Paper presented at the 5th Annual Meeting of The American College of Clinical Pharmacology and Chemotherapy, May 2-4, 1968. Atlantic City, New Jersey. 10. Zsigmond, E. K.: Letter to the Editor. J.A.M.A. $221: 712$ (1972).

Reprint requests should be sent to: Elemér $\mathrm{K}$. Zsigmond, M.D., Univ. of Michigan Med. Center, Dept. of Anesthesiology, Ann Arbor, Michigan 48104. 